\title{
Final five-year outcomes after implantation of biodegradable polymer-coated biolimus-eluting stents versus durable polymer-coated sirolimus-eluting stents
}

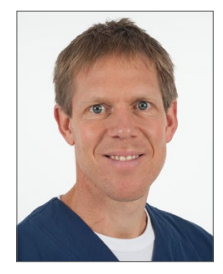

Lars Jakobsen $^{1 *}$, MD, PhD; Evald H. Christiansen ${ }^{1}, \mathrm{MD}$, PhD; Michael Maeng ${ }^{1}, \mathrm{MD}, \mathrm{PhD}$; Knud N. Hansen², MD; Steen D. Kristensen ${ }^{1}$, MD, DMSci; Hans E. Bøtker ${ }^{1}$, MD, DMSci, PhD; Christian J. Terkelsen ${ }^{1}$, MD, DMSci, PhD; Svend E. Jensen ${ }^{3}, \mathrm{MD}, \mathrm{PhD}$;

Bent Raungaard ${ }^{3}, \mathrm{MD}, \mathrm{PhD}$; Morten Madsen ${ }^{4}$, MSc; Jens F. Lassen'1, MD, PhD; Lisette O. Jensen², MD, DMSci, PhD; for the SORT OUT (Scandinavian Organization for

Randomized Trials with Clinical Outcome) V investigators

1. Department of Cardiology, Aarhus University Hospital, Aarhus, Denmark; 2. Department of Cardiology, Odense University Hospital, Odense, Denmark; 3. Department of Cardiology, Aalborg University Hospital, Aalborg, Denmark; 4. Department of Clinical Epidemiology, Aarhus University Hospital, Aarhus, Denmark

\section{KEYWORDS}

- drug-eluting stent

- in-stent restenosis

- stent thrombosis

\section{Abstract}

Aims: Our aim was to report the long-term safety and efficacy of the biodegradable polymer-coated biolimus-eluting Nobori stent compared to the durable polymer-coated sirolimus-eluting CYPHER stent.

Methods and results: SORT OUT V randomised 2,468 patients 1:1 to the Nobori $(n=1,229)$ versus the CYPHER stent $(n=1,239)$. Clinically driven event detection based on Danish registries was used. The primary endpoint was a composite of safety (cardiac death, myocardial infarction, definite stent thrombosis) and efficacy (target vessel revascularisation). Individual components of the primary endpoint comprise the secondary endpoints. At five-year follow-up, the composite endpoint rate was found to be similar in patients treated with the two study stents (Nobori 182/1,229 [14.8\%] vs. CYPHER 197/1,239 [15.8\%]; odds ratio [OR] 0.93, 95\% CI: 0.75-1.16; $\mathrm{p}=0.53$ ). The rates of definite stent thrombosis were also found to be similar in patients treated with the two study stents (Nobori 23/1,229 [1.9\%] vs. CYPHER 18/1,239 [1.5\%]; OR $1.31,95 \%$ CI: $0.70-2.47 ; \mathrm{p}=0.40$ ), as were the other secondary endpoints.

Conclusions: At five-year follow-up, the Nobori stent with a biodegradable polymer coating provided a similar safety and efficacy profile when compared to the durable polymer first-generation CYPHER stent.

*Corresponding author: Department of Cardiology, Aarhus University Hospital, Palle Juul-Jensens Boulevard 99, DK-8200 Aarhus, Denmark. E-mail: larsj@dadlnet.dk 


$\begin{array}{ll}\text { Abbreviations } \\ \text { ARC } & \text { Academic Research Consortium } \\ \text { DES } & \text { drug-eluting stent(s) } \\ \text { MACE } & \text { major adverse cardiac events } \\ \text { OR } & \text { odds ratio } \\ \text { SORT OUT } & \text { Scandinavian Organization for Randomized Trials } \\ & \text { with Clinical Outcome } \\ \text { ST } & \text { stent thrombosis } \\ \text { TVR } & \text { target vessel revascularisation }\end{array}$

\section{Introduction}

The controlled release of antiproliferative drugs from coronary stents significantly reduced the risk of restenosis and the need for repeat revascularisation compared to bare metal stents ${ }^{1}$. However, first-generation drug-eluting stents (DES) with durable polymers have presented an increased risk of stent thrombosis (ST), especially very late ST after discontinuation of dual antiplatelet therapy ${ }^{2}$. Incomplete endothelialisation of the stent struts and positive vessel remodelling due to vessel wall inflammation were considered to be causal factors, probably triggered by the persisting polymer material of first-generation $\mathrm{DES}^{3}$. Biodegradable polymer DES were developed to overcome this problem by providing controlled drug release combined with degradation of the polymer. The biolimuseluting Nobori ${ }^{\circledR}$ stent (Terumo Corp., Tokyo, Japan) was designed with a biodegradable polymer applied to the abluminal surface of the stent. After implantation and drug elution, the polymer is metabolised to water and carbon dioxide within nine months ${ }^{4}$.

The SORT OUT (Scandinavian Organization for Randomized Trials with Clinical Outcome) V trial failed to demonstrate noninferiority of the Nobori as compared to the CYPHER ${ }^{\circledR}$ stent (Cordis, Cardinal Health, Milpitas, CA, USA) in the composite safety and efficacy endpoint and in occurrence of definite ST at nine-month follow-up 5 . In this study, we present five-year clinical outcomes.

Editorial, see page 1263

\section{Methods}

\section{STUDY DESIGN AND PATIENTS}

The SORT OUT V study protocol has been described previously 5 . Briefly, SORT OUT V is a multicentre, open-label, all-comers study comparing the biolimus-eluting Nobori stent to the sirolimus-eluting CYPHER stent in treating coronary artery stenoses. Eligible patients were at least 18 years old, had chronic stable coronary artery disease or acute coronary syndromes, and at least one coronary artery lesion with more than $50 \%$ diameter stenosis requiring treatment with a DES. No restrictions were placed on the number of treated lesions, number of treated vessels, or lesion length. Exclusion criteria were less than one-year life expectancy; allergy to aspirin, clopidogrel, prasugrel, sirolimus, or biolimus; participation in another randomised trial; inability to tolerate dual antiplatelet treatment for 12 months; or inability to provide written informed consent. The study complied with the Declaration of Helsinki and was approved by the local ethics committee. All patients provided written informed consent for trial participation. Before implantation, patients received at least $75 \mathrm{mg}$ of aspirin, a $600 \mathrm{mg}$ loading dose of clopidogrel, and an unfractionated heparin dose (5,000 IU or 70-100 IU/kg). The recommended post-procedure dual antiplatelet regimen was $75 \mathrm{mg}$ aspirin daily lifelong and clopidogrel $75 \mathrm{mg}$ for one year.

\section{RANDOMISATION}

Patients were enrolled by the investigators and randomly allocated to the treatment groups after diagnostic coronary angiography and before percutaneous coronary intervention. Block randomisation by centre was used to assign patients in a 1:1 ratio to receive the Nobori or the CYPHER stent. An independent organisation computer-generated the allocation sequence, stratified by gender, and presence of diabetes or ST-segment elevation myocardial infarction. Patients were assigned to treatment through an automated telephone allocation service. While operators were not blinded, all individuals analysing data were masked to treatment assignment.

\section{OUTCOMES}

Follow-up was pre-specified after nine and 12 months, and five years. The primary endpoint was nine-month major adverse cardiac events (MACE), defined as the composite of cardiac death, myocardial infarction, definite ST, or target vessel revascularisation (TVR) ${ }^{5}$. In the present study, we assessed MACE after five years. Secondary endpoints were all-cause death, cardiac death, myocardial infarction, ARC-defined definite $\mathrm{ST}^{6}$, TVR, and target lesion revascularisation (stent plus $5 \mathrm{~mm}$ distal and proximal edges).

\section{CLINICAL EVENT DETECTION}

We used clinically driven event detection based on national Danish registry data to avoid study-induced reinterventions ${ }^{5,7}$. An independent events committee, masked to treatment group assignment during the adjudication process, reviewed all endpoints and source documents to adjudicate causes of death, reasons for hospital admission, and diagnosis of myocardial infarction. Two dedicated percutaneous coronary intervention operators at each participating centre reviewed cine films for the event committee to classify ST and target vessel revascularisation (either with percutaneous coronary intervention or with coronary artery bypass grafting). In cases of different interpretations, the angiograms were re-evaluated to obtain consensus.

\section{STATISTICAL ANALYSIS}

The trial was powered for assessing non-inferiority of the Nobori stent to the CYPHER stent with respect to the primary endpoint. Follow-up began on the date of the index percutaneous coronary intervention procedure. In analyses of each outcome, follow-up continued until the date of an endpoint event, death, emigration, or until five years after implantation, whichever occurred first. We constructed cumulative incidence curves for each endpoint, taking into account death as a competing risk. Additionally, we carried 
out landmark analyses to assess outcomes at one year and between one year and five years. Multiplicative interaction between subgroup and stent type was calculated with Wald statistics. We estimated differences between groups by calculating odds ratios. Patients who received the CYPHER stent were used as the reference group in the analyses. Odds ratios were calculated for MACE at five-year follow-up for pre-specified patient subgroups. All analyses were performed by intention to treat. We used SAS software, version 9.4 (SAS Institute, Cary, NC, USA) for all analyses.

\section{Results}

\section{PATIENTS AND ENROLMENT}

A total of 2,468 patients with 3,087 lesions were randomly assigned to receive either the Nobori (1,229 patients; 1,532 lesions) or the CYPHER stent (1,239 patients; 1,555 lesions). One patient in each group was lost to follow-up due to emigration. The trial flow diagram is provided in Figure 1.

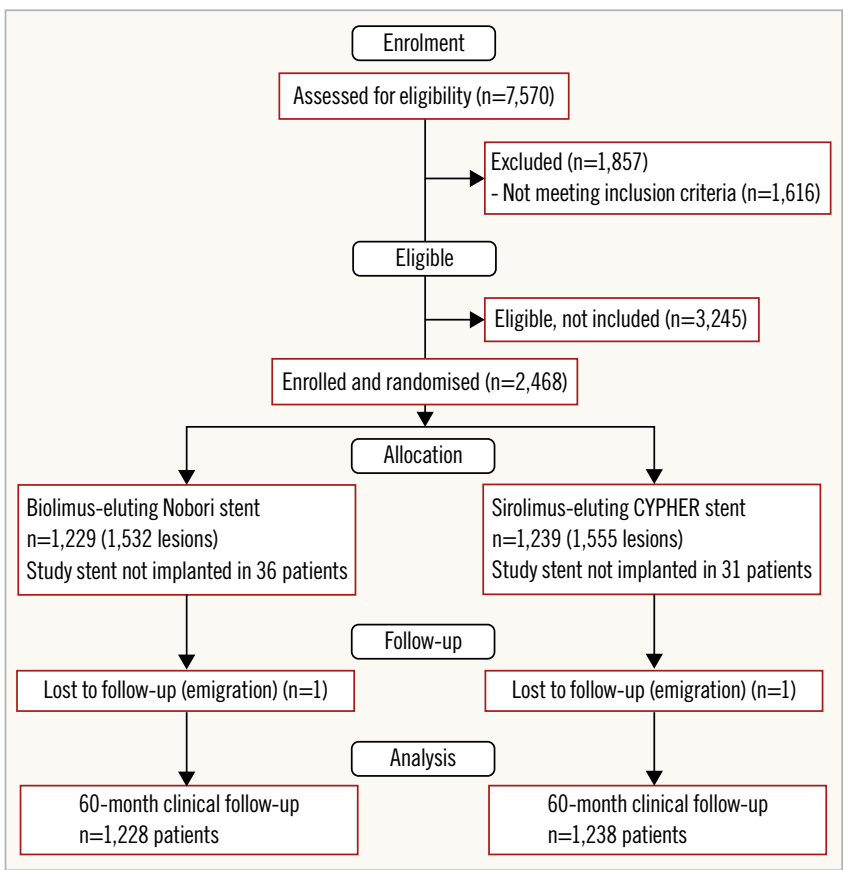

Figure 1. Trial profile of the SORT OUT V trial.

Baseline demographic and clinical characteristics in the two study groups are shown in Table 1. Overall, the treatment groups were well matched, but there were more patients with previous coronary artery bypass grafting in the Nobori stent group.

Table 2 presents the five-year clinical outcomes and the landmark analyses of events occurring within and after year 1 . The Figures illustrate these outcomes and analyses for MACE (Figure 2), cardiac death (Figure 3), myocardial infarction (Figure 4), TVR (Figure 5), and definite ST (Figure 6). At fiveyear follow-up, clinical outcomes did not differ significantly between patients who received Nobori and those who received CYPHER stents (Table 2). Patients in the Nobori stent group had
Table 1. Baseline characteristics of the study population.

\begin{tabular}{|c|c|c|c|c|}
\hline & $\begin{array}{c}\text { Biolimus-eluting } \\
\text { Nobori stent } \\
(\mathrm{N}=1,229)(\mathrm{n} / \%)\end{array}$ & $\begin{array}{c}\text { Sirolimus-eluting } \\
\text { CYPHER stent } \\
(\mathrm{N}=1,239)(\mathrm{n} / \%)\end{array}$ & $p$-value \\
\hline \multicolumn{2}{|c|}{ Age, yrs, mean (SD) } & $65.0 \pm 10.6$ & $65.2 \pm 10.3$ & 0.51 \\
\hline \multicolumn{2}{|l|}{ Male } & $917(74.6 \%)$ & $930(75.1 \%)$ & 0.80 \\
\hline \multicolumn{2}{|c|}{ Diabetes mellitus } & $185 / 1,229(15.1 \%)$ & $189 / 1,239(15.3 \%)$ & 0.89 \\
\hline \multicolumn{2}{|c|}{ Arterial hypertension } & $682 / 1,180(57.8 \%)$ & $653 / 1,189(54.9 \%)$ & 0.28 \\
\hline \multicolumn{2}{|c|}{ Hypercholesterolaemia } & $710 / 1,179(60.2 \%)$ & $730 / 1,190(61.3 \%)$ & 0.81 \\
\hline \multicolumn{2}{|c|}{ Current smoker } & $385 / 1,145(33.6 \%)$ & $381 / 1,152(33.1 \%)$ & 0.78 \\
\hline \multicolumn{2}{|c|}{$\begin{array}{l}\text { Body mass index, } \mathrm{kg} / \mathrm{m}^{2} \text {, mean } \\
\text { (SD) }\end{array}$} & $27.5 \pm 5.2$ & $27.4 \pm 5.2$ & 0.66 \\
\hline \multicolumn{2}{|c|}{ Previous myocardial infarction } & 209/1,182 (17.7\%) & $206 / 1,189(17.3 \%)$ & 0.82 \\
\hline \multicolumn{2}{|c|}{$\begin{array}{l}\text { Previous percutaneous } \\
\text { coronary intervention }\end{array}$} & 205/1,182 (17.3\%) & $196 / 1,191(16.5 \%)$ & 0.56 \\
\hline \multicolumn{2}{|c|}{$\begin{array}{l}\text { Previous coronary artery } \\
\text { bypass grafting }\end{array}$} & $96 / 1,184(8.1 \%)$ & $71 / 1,195$ (5.9\%) & 0.039 \\
\hline \multirow[t]{4}{*}{$\begin{array}{l}\text { Indication for } \\
\text { percutaneous } \\
\text { coronary } \\
\text { intervention }\end{array}$} & $\begin{array}{l}\text { ST-segment } \\
\text { elevation } \\
\text { myocardial } \\
\text { infarction }\end{array}$ & 225 (18.3\%) & $227(18.3 \%)$ & \multirow{4}{*}{0.70} \\
\hline & $\begin{array}{l}\text { Non-ST- } \\
\text { segment } \\
\text { elevation } \\
\text { myocardial } \\
\text { infarction or } \\
\text { unstable } \\
\text { angina }\end{array}$ & $372(30.3 \%)$ & $384(31.0 \%)$ & \\
\hline & Stable angina & $608(49.5 \%)$ & $596(48.1 \%)$ & \\
\hline & Other & $24(2.0 \%)$ & $32(2.6 \%)$ & \\
\hline
\end{tabular}

higher MACE rates within the first year (OR 1.23, 95\% CI: 0.85 $1.79 ; \mathrm{p}=0.27$ ) and lower rates beyond the first year (OR $0.82,95 \%$ CI: 0.63-1.07; p=0.14). Findings for MACE rates were consistent across pre-specified subgroups (Figure 7).

\section{Discussion}

SORT OUT V is the largest head-to-head comparison of the biodegradable polymer-coated biolimus-eluting Nobori stent versus the durable polymer-coated sirolimus-eluting CYPHER stent. After five years, the Nobori stent did not reduce risk of death, cardiac death, myocardial infarction, definite ST, or TVR compared to the CYPHER stent.

During the first year the Nobori stent group had a $0.8 \%$ definite ST rate. Recently, in the SORT OUT VII trial, we also found a higher one-year risk of definite ST in Nobori-treated patients $(1.2 \%)$ compared to the biodegradable polymer sirolimus-eluting Orsiro stent $(0.4 \%)$ (Biotronik, Berlin, Germany) ${ }^{8}$. The COMPARE II trial found similar numerically higher definite ST in $0.7 \%$ in the Nobori group compared to the durable polymer-coated everolimus-eluting stent group $(0.4 \%)$ at one year ${ }^{9}$, as did the NEXT trial $(0.25 \%$ in the Nobori arm compared to $0.06 \%$ in everolimus-eluting stents at one year) ${ }^{10}$. The Long Drug-Eluting Stent (LONG-DES) trial compared the Nobori and the durable polymer-based platinum-chromium everolimus-eluting stent (PtCr-EES) in patients with long ( $\geq 25 \mathrm{~mm})$ lesions, and found $0.8 \%$ definite ST in the 
A

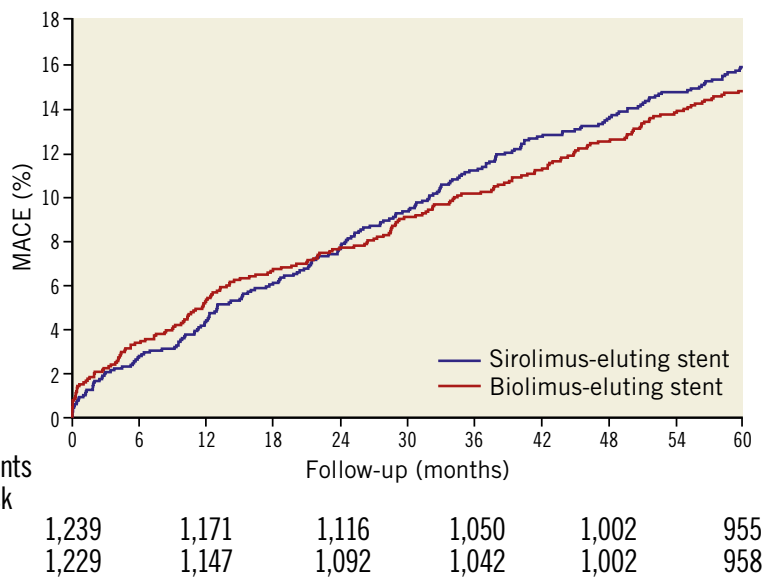

B

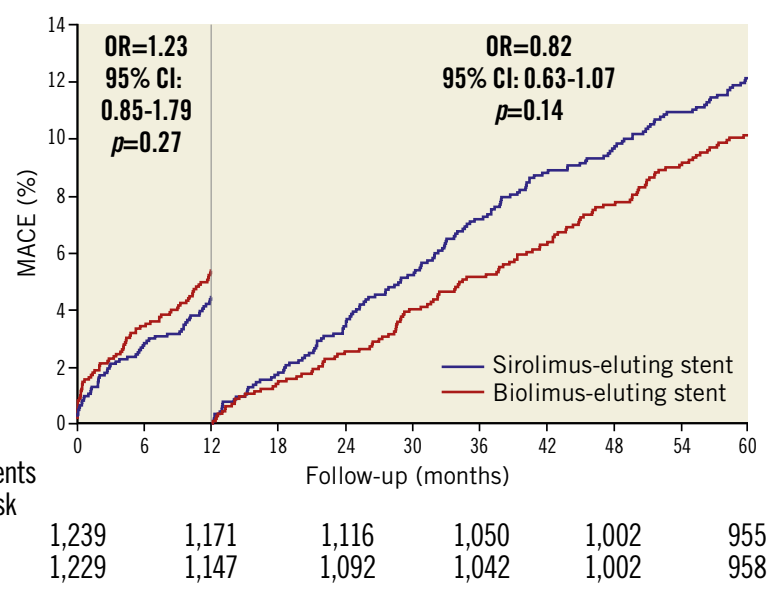

Figure 2. Major adverse cardiac events in the SORT OUT V trial. A) Event rates of major adverse cardiac events (cardiac death, myocardial infarction, definite stent thrombosis and target vessel revascularisation) in the biolimus-eluting stent and sirolimus-eluting stent groups.

B) Landmark analysis discriminating between events occurring before and after one year of follow-up. OR: odds ratio

A

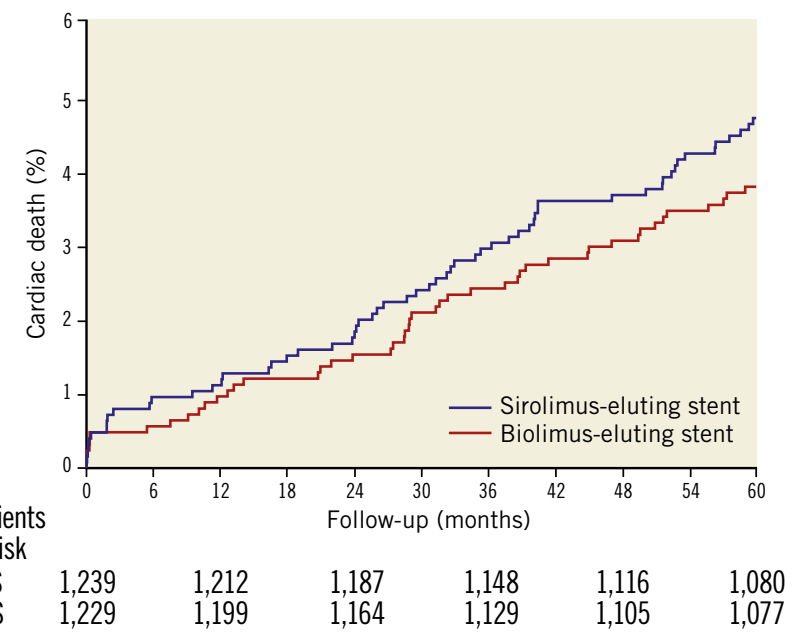

B

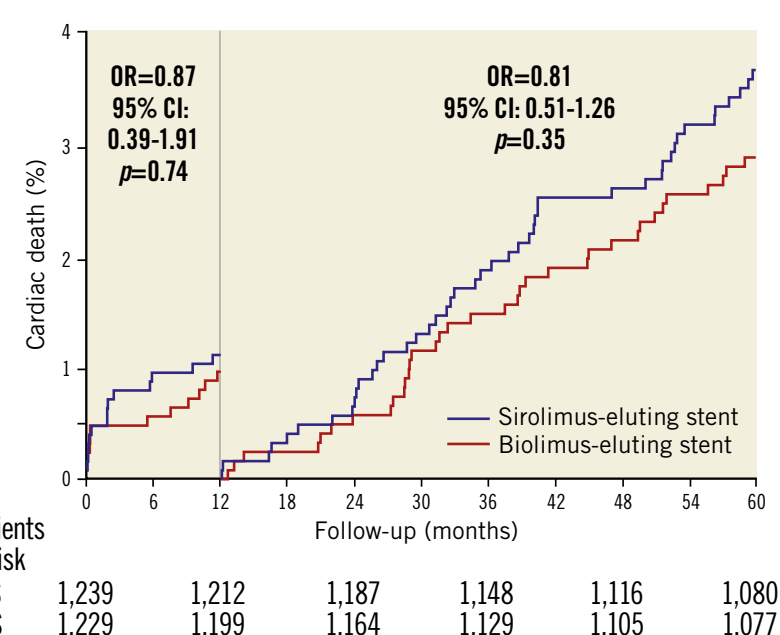

Figure 3. Cardiac death in the SORT OUT V trial. A) Event rates of cardiac death in the biolimus-eluting stent and sirolimus-eluting stent groups. B) Landmark analysis discriminating between events occurring before and after one year of follow-up. OR: odds ratio

A

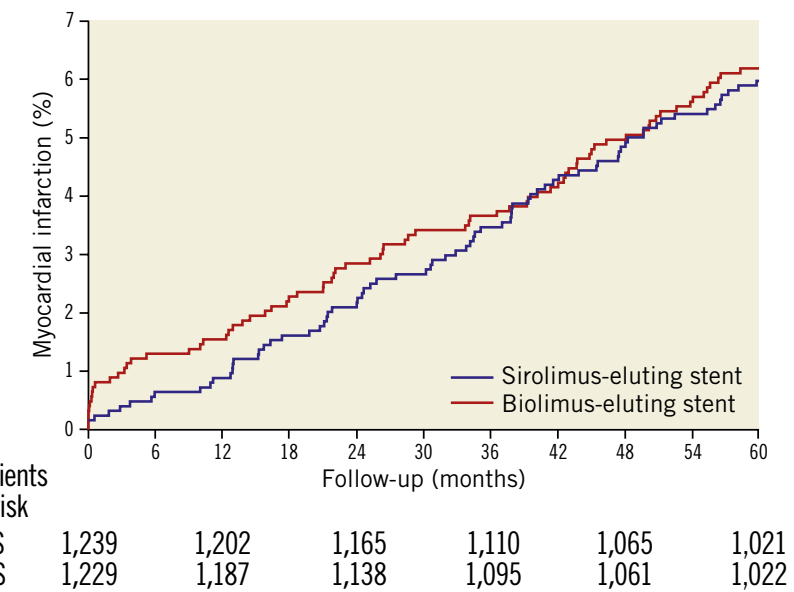

B

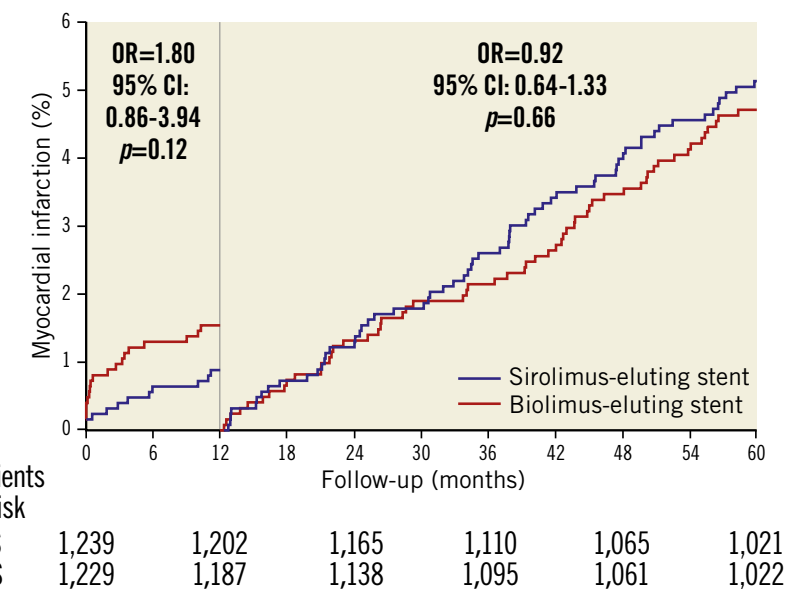

Figure 4. Myocardial infarction in the SORT OUT V trial. A) Event rates of myocardial infarction in the biolimus-eluting stent and sirolimuseluting stent groups. B) Landmark analysis discriminating between events occurring before and after one year of follow-up. OR: odds ratio 
Table 2. Five-year clinical outcomes in the SORT OUT V trial.

\begin{tabular}{|c|c|c|c|c|}
\hline & $\begin{array}{l}\text { Biolimus- } \\
\text { eluting Nobori } \\
\text { stent } \\
(\mathrm{N}=1,229)\end{array}$ & $\begin{array}{l}\text { Sirolimus- } \\
\text { eluting } \\
\text { CYPHER stent } \\
(\mathrm{N}=1,239)\end{array}$ & OR (95\% Cl) & $p$-value \\
\hline $\begin{array}{l}\text { Events at 0-5 } \\
\text { years }\end{array}$ & $\begin{array}{c}\text { No. of patients } \\
(\%)\end{array}$ & $\begin{array}{c}\text { No. of patients } \\
(\%)\end{array}$ & & \\
\hline $\begin{array}{l}\text { Combined endpoint } \\
\text { (MACE)* }\end{array}$ & $182(14.8)$ & $197(15.8)$ & $0.93(0.75-1.16)$ & 0.53 \\
\hline Death & $151(12.3)$ & $158(12.8)$ & $0.97(0.76-1.25)$ & 0.83 \\
\hline Cardiac death & $47(3.8)$ & $59(4.8)$ & $0.81(0.54-1.20)$ & 0.30 \\
\hline $\begin{array}{l}\text { Myocardial } \\
\text { infarction }\end{array}$ & $76(6.2)$ & $74(6.0)$ & $1.05(0.75-1.47)$ & 0.76 \\
\hline \begin{tabular}{|l|} 
Definite stent \\
thrombosis
\end{tabular} & $23(1.9)$ & $18(1.5)$ & $1.31(0.70-2.47)$ & 0.40 \\
\hline $\begin{array}{l}\text { Target lesion } \\
\text { revascularisation }\end{array}$ & $76(6.2)$ & $79(6.4)$ & $0.97(0.70-1.34)$ & 0.85 \\
\hline $\begin{array}{l}\text { Target vessel } \\
\text { revascularisation }\end{array}$ & $107(8.7)$ & $118(9.5)$ & $0.92(0.69-1.21)$ & 0.54 \\
\hline 0-1 year & $\begin{array}{c}\text { No. of patients } \\
(\%)\end{array}$ & $\begin{array}{c}\text { No. of patients } \\
(\%)\end{array}$ & & \\
\hline $\begin{array}{l}\text { Combined endpoint } \\
\text { (MACE)* }\end{array}$ & $66(5.4)$ & $55(4.4)$ & $1.23(0.85-1.79)$ & 0.27 \\
\hline Death & $30(2.4)$ & $27(2.2)$ & $1.14(0.67-1.96)$ & 0.62 \\
\hline Cardiac death & $12(1.0)$ & $14(1.1)$ & $0.87(0.39-1.91)$ & 0.74 \\
\hline $\begin{array}{l}\text { Myocardial } \\
\text { infarction }\end{array}$ & $19(1.5)$ & $11(0.9)$ & $1.80(0.86-3.94)$ & 0.12 \\
\hline $\begin{array}{l}\text { Definite stent } \\
\text { thrombosis }\end{array}$ & $10(0.8)$ & $3(0.2)$ & 3.41 (1.04-15.3) & 0.06 \\
\hline $\begin{array}{l}\text { Target lesion } \\
\text { revascularisation }\end{array}$ & $40(3.3)$ & $25(2.0)$ & $1.64(1.00-2.76)$ & 0.054 \\
\hline $\begin{array}{l}\text { Target vessel } \\
\text { revascularisation }\end{array}$ & $52(4.2)$ & $39(3.1)$ & $1.37(0.90-2.10)$ & 0.15 \\
\hline$>1$ year-5 years" & $\begin{array}{c}\text { No. of patients } \\
(\%)\end{array}$ & $\begin{array}{c}\text { No. of patients } \\
(\%)\end{array}$ & & \\
\hline $\begin{array}{l}\text { Combined endpoint } \\
\text { (MACE)* }^{*}\end{array}$ & $116(10.1)$ & $142(12.1)$ & $0.82(0.63-1.07)$ & 0.14 \\
\hline Death & $121(10.1)$ & $131(10.8)$ & $0.95(0.72-1.24)$ & 0.69 \\
\hline Cardiac death & $35(2.9)$ & $45(3.7)$ & $0.81(0.51-1.26)$ & 0.35 \\
\hline $\begin{array}{l}\text { Myocardial } \\
\text { infarction }\end{array}$ & $57(4.7)$ & $63(5.1)$ & $0.92(0.64-1.33)$ & 0.66 \\
\hline $\begin{array}{l}\text { Definite stent } \\
\text { thrombosis }\end{array}$ & $13(1.1)$ & $15(1.2)$ & $0.89(0.42-1.89)$ & 0.77 \\
\hline $\begin{array}{l}\text { Target lesion } \\
\text { revascularisation }\end{array}$ & $36(3.0)$ & $54(4.5)$ & $0.67(0.43-1.03)$ & 0.068 \\
\hline $\begin{array}{l}\text { Target vessel } \\
\text { revascularisation }\end{array}$ & $55(4.7)$ & $79(6.6)$ & $0.70(0.49-0.99)$ & 0.047 \\
\hline \multicolumn{5}{|c|}{$\begin{array}{l}\text { *Composite of cardiac death, myocardial infarction, definite stent } \\
\text { thrombosis, or clinically driven target vessel revascularisation. "The } \\
\text { denominators used to calculate the percentages in this section of the } \\
\text { table are lower because some patients died during the first year. } \\
\text { MACE: major adverse cardiac events; OR: odds ratio }\end{array}$} \\
\hline
\end{tabular}

Nobori arm and none in the PtCr-EES arm ${ }^{11}$. Thus, Nobori stent treatment was associated with higher risk of ST during the first year in all these trials. The biodegradable polymer biolimus-eluting BioMatrix Flex ${ }^{\mathrm{TM}}$ stent (Biosensors Interventional Technologies Pte Ltd., Singapore) has similarities to the Nobori stent. Both stents are made of the same stainless steel alloy, have a strut thickness of $112 \mu \mathrm{m}$, are coated with the same biodegradable polymer and both elute biolimus A9. However, the Nobori stent utilises an ultrathin non-degradable parylene-C coating between the struts and the polymer to assure polymer attachment, and the stents are mounted on different balloons and delivery catheters. The BioMatrix Flex showed fewer cases of definite ST during the first year compared to the comparator stent in LEADERS ${ }^{12,13}$ and in SORT OUT VI ${ }^{14}$. The reason for this difference in outcome is not clear but could be due to differences in the coating as well as differences in the balloon delivery systems. The studies further suggest that it cannot be justified to consider the Nobori and BioMatrix Flex the same stent as they were in the network meta-analyses ${ }^{15,16}$.

From one to five years we observed a very late ST rate of $0.27 \%$ year $(13$ of 1,192$)$ in the Nobori group, a rate almost similar to the NEXT and the COMPARE II trials ${ }^{17}$. The rate is slightly higher than reported for the BioMatrix Flex stent in LEADERS $^{18}(0.16 \%$ /year, five of 804$)$, but similar to the SORT OUT VI trial from year 1 to year $3(0.33 \% \text { /year, } 10 \text { of } 1,497)^{19}$. Thus, the present data do not support that the permanent parylene-C coating gives rise to a higher risk of very late $\mathrm{ST}^{5}$. The very late ST rate with permanent polymer zotarolimus-eluting stents in SORT OUT III ${ }^{20}$ was only $0.02 \%$ /year (one of 1,162 ) and only $0.05 \%$ /year (three of 1,390 ) with the durable polymercoated everolimus-eluting stent ${ }^{21}$. Therefore, in the SORT OUT trials, the thin-strut permanent polymer second-generation stents had lower risk of very late ST compared to both first-generation permanent polymer DES and third-generation stainless steel thick-strut biodegradable polymer stents. Further support for protection against ST by the use of thin-strut permanent polymer stents compared to a bare metal platform comes from the NORSTENT trial (The Norwegian Coronary Stent Trial) ${ }^{22}$. After six years, definite ST occurred in $0.8 \%$ in the DES arm $(96 \%$ second-generation) compared to $1.2 \%$ in the bare metal stent arm $(\mathrm{p}<0.05)$.

\section{COMBINED ENDPOINT AT FIVE YEARS}

The MACE rate and the individual endpoints were similar in the Nobori and CYPHER groups. This confirms the LEADERS trial, in which the MACE rate was $22.3 \%$ in the biolimus-eluting stent versus $26.1 \%$ in the sirolimus-eluting stent groups $(p=n s)^{18}$. The ISAR-TEST (Intracoronary Stenting and Angiographic Results) 4 trial compared a biodegradable polymer stent to the durable polymer sirolimus-eluting CYPHER stent and the everolimus-eluting stent. At three-year follow-up, there was no difference between biodegradable polymer-coated and durable polymer-coated DES with regard to the primary endpoint of MACE (20.1\% vs. $20.9 \%$ ). However, in a meta-analysis of ISAR-TEST 3, ISAR-TEST 4 and LEADERS $^{23}$, the MACE rate was marginally lower after four years $(19.0 \%$ versus $21.6 \%)$ in biodegradable polymer-coated biolimus-eluting stents. Thus, the use of some biodegradable polymer-coated stents may hold the potential of improving long-term safety when compared to some durable polymer-coated DES, but SORT OUT V does not support this for the Nobori stent. 


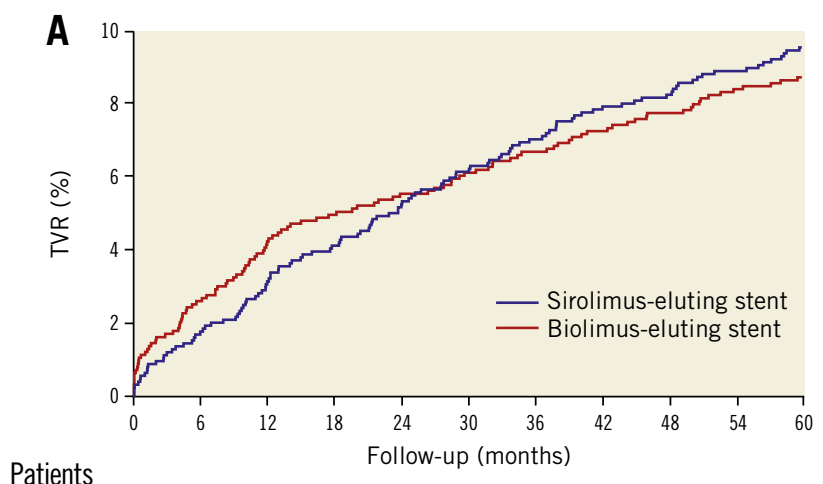

Patients

at risk

$\begin{array}{lllrrr}\text { SES } & 1,239 & 1,174 & 1,125 & 1,066 & 1,023\end{array}$

$\begin{array}{llllll}\text { BES } & 1,229 & 1,152 & 1,105 & 1,060 & 1,028\end{array}$

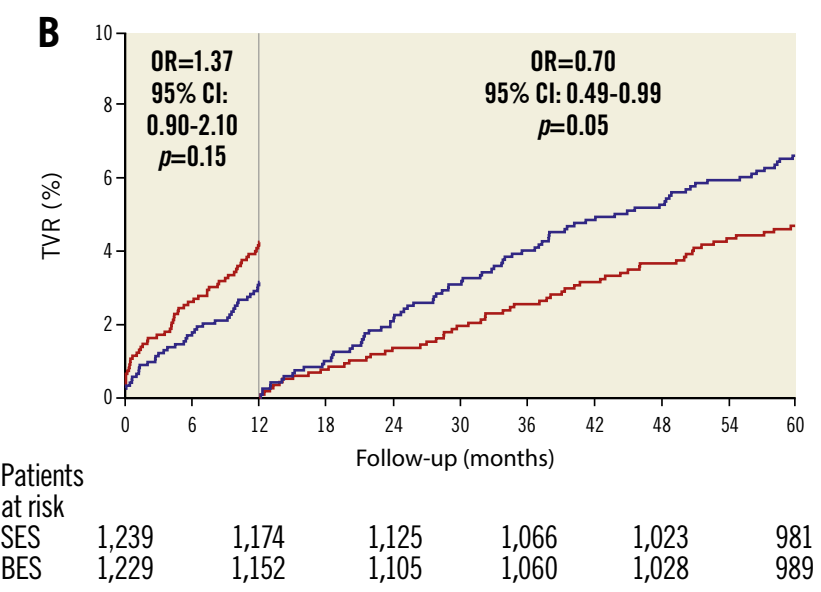

Figure 5. Target vessel revascularisation in the SORT OUT V trial. A) Event rates of target vessel revascularisation in the biolimus-eluting stent and sirolimus-eluting stent groups. B) Landmark analysis discriminating between events occurring before and after one year of follow-up. OR: odds ratio
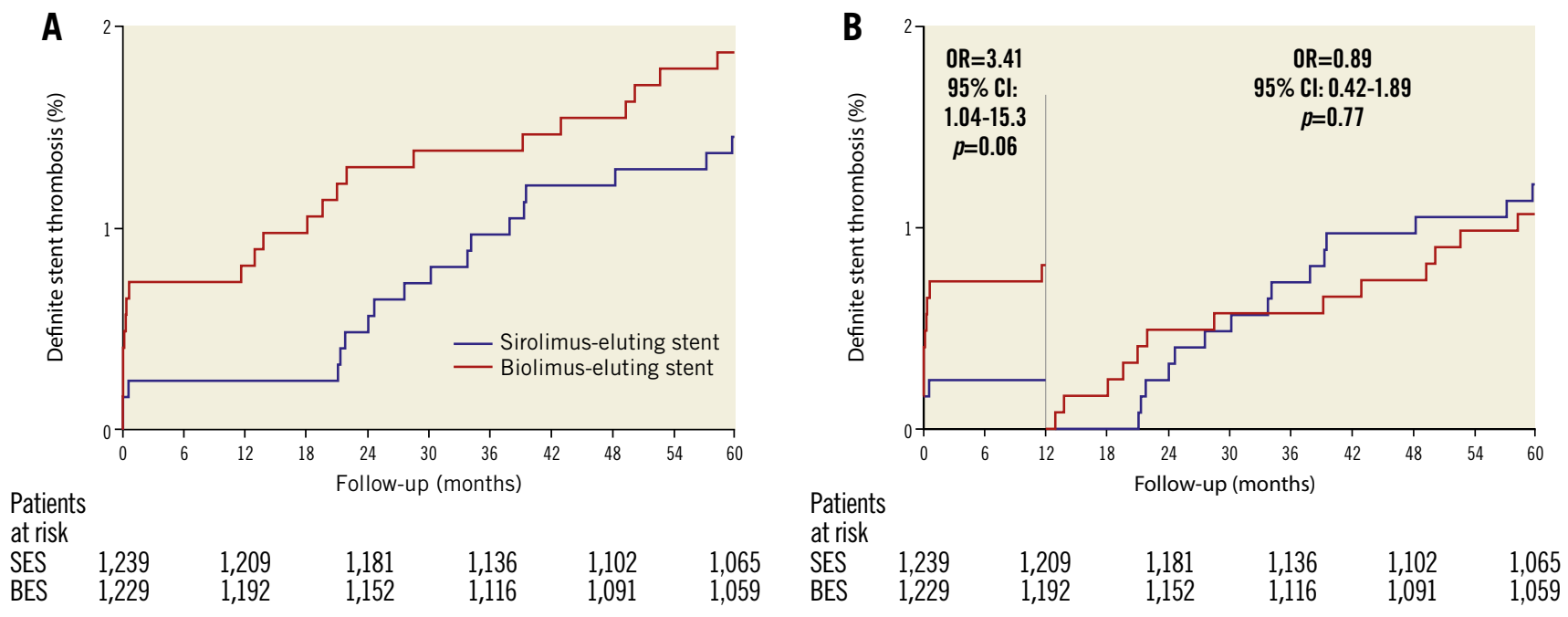

Figure 6. Definite stent thrombosis in the SORT OUT V trial. A) Event rates of definite stent thrombosis in the biolimus-eluting stent and sirolimus-eluting stent groups. B) Landmark analysis discriminating between events occurring before and after one year of follow-up. OR: odds ratio

All SORT OUT trials used the "registry-based randomised clinical trial design" ${ }_{5,7}$. Advantages include a reduction in cost because of the use of established registries and very high follow-up rates. Furthermore, it provides event rates in real-life patients whereas patients included in trials with routine follow-up may have more reinterventions. Although the Danish healthcare databases capture events for patients seeking medical attention, these records might underestimate event rates. Revascularisation is, however, registered in two registries, the Danish National Registry of Patients and the Western Denmark Heart Registry, and it is therefore unlikely that revascularisations can occur without being captured. A myocardial infarction can be missed if a misclassification of the diagnosis code occurs in a patient file (classified with a noncardiac diagnosis) and consequently misreported in the Danish National Registry of Patients. However, all myocardial infarctions leading to angiography will be captured in the Western Denmark Heart Registry. Silent myocardial infarctions not leading to hospital admission will not be captured in our design in contrast to a conventional design where follow-up ECGs are required. A minor underestimation of myocardial infarctions should, however, not lead to bias on the differences detected between treatment groups, and the negligible loss to follow-up in the SORT OUT design probably compensates for this potential underestimation of myocardial infarctions.

\section{Limitations}

The SORT OUT design has other limitations. Data for the duration of dual antiplatelet therapy are not collected. However, all patients were recommended to receive 12 months of dual antiplatelet therapy, and all patients received reimbursement of costs. We used 


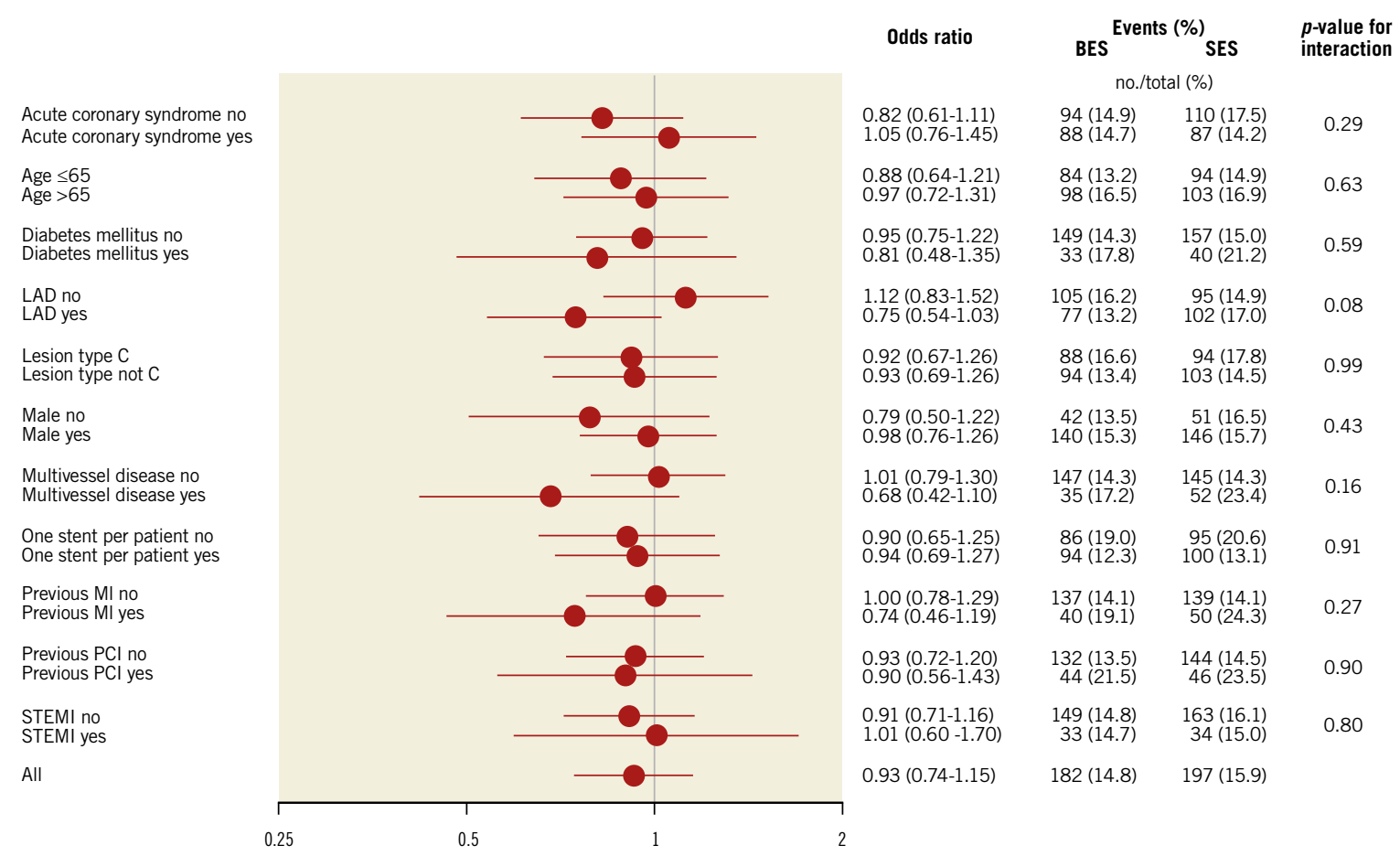

Figure 7. Stratified analysis of the primary endpoint at five years in patients randomly assigned to implantation with the biodegradable polymer biolimus-eluting stent (BES) or durable polymer sirolimus-eluting stent (SES). Data are numbers of patients. Major adverse cardiac events are a composite of cardiac death, myocardial infarction, definite stent thrombosis, and target vessel revascularisation. LAD: left anterior descending artery; MI: myocardial infarction; PCI: percutaneous coronary intervention; STEMI: ST-segment elevation myocardial infarction

broad inclusion criteria to include routine clinical care patients, but SORT OUT V included only $43 \%$ of eligible patients. This was mainly caused by some operators not being willing to include patients, whereas other operators included $80 \%$ of patients. A significant proportion of eligible ST-segment elevation myocardial infarction patients was not included and this raises concerns on external validity. Still, we found no interaction between ST-segment elevation myocardial infarction and stent group. It should be noted that we found very low rates of adverse outcomes, including very late stent thrombosis, for the CYPHER stent compared to some other trials $\left(1.5 \%\right.$ vs. $5.2 \%$ in LEADERS $\left.^{18}\right)$. The better than expected performance of the CYPHER stent could be due to some difference in the study populations because of the low inclusion rate mentioned above.

\section{Conclusions}

At five-year follow-up, the Nobori stent with a biodegradable polymer coating provided similar safety and efficacy profiles when compared to the durable polymer first-generation CYPHER stent. Despite a biodegradable polymer, the biolimus-eluting Nobori stent had similar risk of very late definite stent thrombosis compared to the sirolimus-eluting CYPHER stent. This is in line with most previous trials where no significant reduction in MACE has been demonstrated with the use of biodegradable polymer stents compared to permanent polymer stents.

\section{Impact on daily practice}

In the selection of stents for coronary revascularisation, the distinction between biodegradable polymer stents versus permanent polymer stents does not seem important for efficacy and safety. Other factors of importance include: 1) patient-related factors (compliance with dual antiplatelet treatment), 2) mechanical factors of the metal backbone (radial strength, strut thickness, and expansion capacity), and 3) operator skills (the ability to achieve an optimal stent result).

\section{Acknowledgements}

We are thankful to Helle Bargsteen for her efficient help with all aspects of the trial.

\section{Funding}

This work was supported by equal unrestricted grants from Terumo and Cordis, Johnson \& Johnson.

\section{Conflict of interest statement}

L.O. Jensen has received unrestricted research grants from Biotronik, Biosensors and St. Jude Medical. M. Maeng has received unrestricted research grants from Biosensors, Volcano and Boston Scientific. The other authors have no conflicts of interest to declare. 


\section{References}

1. Morice MC, Serruys PW, Sousa JE, Fajadet J, Ban Hayashi E, Perin M, Colombo A, Schuler G, Barragan P, Guagliumi G, Molnar F, Falotico R; RAVEL Study Group. Randomized Study with the Sirolimus-Coated Bx Velocity Balloon-Expandable Stent in the Treatment of Patients with de Novo Native Coronary Artery Lesions. A randomized comparison of a sirolimus-eluting stent with a standard stent for coronary revascularization. $N$ Engl J Med. 2002;346:1773-80

2. Daemen J, Wenaweser P, Tsuchida K, Abrecht L, Vaina S, Morger C, Kukreja N, Jüni P, Sianos G, Hellige G, van Domburg RT, Hess OM, Boersma E, Meier B, Windecker S, Serruys PW. Early and late coronary stent thrombosis of sirolimus-eluting and paclitaxel-eluting stents in routine clinical practice: data from a large two-institutional cohort study. Lancet. 2007;369:667-78.

3. Joner M, Finn AV, Farb A, Mont EK, Kolodgie FD, Ladich E, Kutys R, Skorija K, Gold HK, Virmani R. Pathology of drug-eluting stents in humans: delayed healing and late thrombotic risk. J Am Coll Cardiol. 2006;48:193-202.

4. Ostojic M, Sagic D, Jung R, Zhang YL, Nedeljkovic M, Mangovski L, Stojkovic S, Debeljacki D, Colic M, Beleslin B, Milosavljevic B, Orlic D, Topic D, Karanovic N, Paunovic D, Christians U; NOBORI PK Investigators. The pharmacokinetics of Biolimus A9 after elution from the Nobori stent in patients with coronary artery disease: the NOBORI PK study. Catheter Cardiovasc Interv. 2008;72:901-8.

5. Christiansen EH, Jensen LO, Thayssen P, Tilsted HH, Krusell LR, Hansen KN, Kaltoft A, Maeng M, Kristensen SD, Botker HE, Terkelsen CJ, Villadsen AB, Ravkilde J, Aaroe J, Madsen M, Thuesen L, Lassen JF; Scandinavian Organization for Randomized Trials with Clinical Outcome (SORT OUT) V investigators. Biolimus-eluting biodegradable polymer-coated stent versus durable polymer-coated sirolimus-eluting stent in unselected patients receiving percutaneous coronary intervention (SORT OUT V): a randomised non-inferiority trial. Lancet. 2013;381:661-9.

6. Cutlip DE, Windecker S, Mehran R, Boam A, Cohen DJ, van Es GA, Steg PG, Morel MA, Mauri L, Vranckx P, McFadden E, Lansky A, Hamon M, Krucoff MW, Serruys PW; Academic Research Consortium. Clinical end points in coronary stent trials: a case for standardized definitions. Circulation. 2007;115:2344-51.

7. Thuesen L, Jensen LO, Tilsted HH, Maeng M, Terkelsen C, Thayssen P, Ravkilde J, Christiansen EH, Botker HE, Madsen M, Lassen JF. Event detection using population-based health care databases in randomized clinical trials: a novel research tool in interventional cardiology. Clin Epidemiol. 2013;5:357-61.

8. Jensen LO, Thayssen P, Maeng M, Ravkilde J, Krusell LR, Raungaard B, Junker A, Terkelsen CJ, Veien KT, Villadsen AB, Kaltoft A, Tilsted HH, Hansen KN, Aaroe J, Kristensen SD, Hansen HS, Jensen SE, Madsen M, Botker HE, Berencsi K, Lassen JF, Christiansen EH. Randomized Comparison of a Biodegradable Polymer Ultrathin Strut Sirolimus-Eluting Stent With a Biodegradable Polymer Biolimus-Eluting Stent in Patients
Treated With Percutaneous Coronary Intervention: The SORT OUT VII Trial. Circ Cardiovasc Interv. 2016 July;9(7).

9. Smits PC, Hofma S, Togni M, Vazquez N, Valdes M, Voudris V, Slagboom T, Goy JJ, Vuillomenet A, Serra A, Nouche RT, den Heijer P, van der Ent M. Abluminal biodegradable polymer biolimus-eluting stent versus durable polymer everolimus-eluting stent (COMPARE II): a randomised, controlled, non-inferiority trial. Lancet. 2013;381:651-60.

10. Natsuaki M, Kozuma K, Morimoto T, Kadota K, Muramatsu T, Nakagawa Y, Akasaka T, Igarashi K, Tanabe K, Morino Y, Ishikawa T, Nishikawa H, Awata M, Abe M, Okada H, Takatsu Y, Ogata N, Kimura K, Urasawa K, Tarutani Y, Shiode N, Kimura T; NEXT Investigators. Biodegradable polymer biolimus-eluting stent versus durable polymer everolimus-eluting stent: a randomized, controlled, noninferiority trial. J Am Coll Cardiol. 2013;62: 181-90.

11. Lee JY, Park DW, Kim YH, Ahn JM, Kim WJ, Kang SJ, Lee SW, Lee CW, Park SW, Yun SC, Yang TH, Lee BK, Lee NH, Yang JY, Shin WY, Park HS, Kim KS, Hur SH, Lee SY, Park JS, Choi YS, Lee SU, Her SH, Park SJ. Comparison of biolimus A9-eluting (Nobori) and everolimus-eluting (Promus Element) stents in patients with de novo native long coronary artery lesions: a randomized Long Drug-Eluting Stent V trial. Circ Cardiovasc Interv. 2014;7:322-9.

12. Stefanini GG, Kalesan B, Serruys PW, Heg D, Buszman P, Linke A, Ischinger T, Klauss V, Eberli F, Wijns W, Morice MC, Di Mario C, Corti R, Antoni D, Sohn HY, Eerdmans P, van Es GA, Meier B, Windecker S, Jüni P. Long-term clinical outcomes of biodegradable polymer biolimus-eluting stents versus durable polymer sirolimus-eluting stents in patients with coronary artery disease (LEADERS): 4 year follow-up of a randomised non-inferiority trial. Lancet. 2011;378:1940-8.

13. Windecker S, Serruys PW, Wandel S, Buszman P, Trznadel S, Linke A, Lenk K, Ischinger T, Klauss V, Eberli F, Corti R, Wijns W, Morice MC, di Mario C, Davies S, van Geuns RJ, Eerdmans P, van Es GA, Meier B, Jüni P. Biolimus-eluting stent with biodegradable polymer versus sirolimus-eluting stent with durable polymer for coronary revascularisation (LEADERS): a randomised non-inferiority trial. Lancet. 2008;372:1163-73.

14. Raungaard B, Jensen LO, Tilsted HH, Christiansen EH, Maeng M, Terkelsen CJ, Krusell LR, Kaltoft A, Kristensen SD, Botker HE, Thuesen L, Aaroe J, Jensen SE, Villadsen AB, Thayssen P, Veien KT, Hansen KN, Junker A, Madsen M, Ravkilde J, Lassen JF; Scandinavian Organization for Randomized Trials with Clinical Outcome (SORT OUT). Zotarolimus-eluting durable-polymer-coated stent versus a biolimus-eluting biodegradable-polymer-coated stent in unselected patients undergoing percutaneous coronary intervention (SORT OUT VI): a randomised non-inferiority trial. Lancet. 2015;385:1527-35.

15. Palmerini T, Biondi-Zoccai G, Della Riva D, Stettler C, Sangiorgi D, D’Ascenzo F, Kimura T, Briguori C, Sabatè M, Kim HS, De Waha A, Kedhi E, Smits PC, Kaiser C, Sardella G, Marullo A, Kirtane AJ, Leon MB, Stone GW. Stent thrombosis with 
drug-eluting and bare-metal stents: evidence from a comprehensive network meta-analysis. Lancet. 2012;379:1393-402.

16. Palmerini T, Benedetto U, Biondi-Zoccai G, Della Riva D, Bacchi-Reggiani L, Smits PC, Vlachojannis GJ, Jensen LO, Christiansen EH, Berencsi K, Valgimigli M, Orlandi C, Petrou M, Rapezzi C, Stone GW. Long-Term Safety of Drug-Eluting and Bare-Metal Stents: Evidence From a Comprehensive Network Meta-Analysis. J Am Coll Cardiol. 2015;65:2496-507.

17. Vlachojannis GJ, Puricel S, Natsuaki M, Morimoto T, Smits PC, Kimura T. Biolimus-eluting versus everolimus-eluting stents in coronary artery disease: a pooled analysis from the NEXT (NOBORI biolimus-eluting versus XIENCE/PROMUS everolimuseluting stent) and COMPARE II (Abluminal biodegradable polymer biolimus-eluting stent versus durable polymer everolimus-eluting stent) randomised trials. EuroIntervention. 2017;12:1970-7.

18. Serruys PW, Farooq V, Kalesan B, de Vries T, Buszman P, Linke A, Ischinger T, Klauss V, Eberli F, Wijns W, Morice MC, Di Mario C, Corti R, Antoni D, Sohn HY, Eerdmans P, RademakerHavinga T, van Es GA, Meier B, Jüni P, Windecker S. Improved safety and reduction in stent thrombosis associated with biodegradable polymer-based biolimus-eluting stents versus durable polymer-based sirolimus-eluting stents in patients with coronary artery disease: final 5-year report of the LEADERS (Limus Eluted From A Durable Versus ERodable Stent Coating) randomized, noninferiority trial. JACC Cardiovasc Interv. 2013;6:777-89.

19. Raungaard B, Christiansen EH, Botker HE, Hansen HS, Ravkilde J, Thuesen L, Aaroe J, Villadsen AB, Terkelsen CJ, Krusell LR, Maeng M, Kristensen SD, Veien KT, Hansen KN, Junker A, Madsen M, Andersen SL, Jensen SE, Jensen LO; SORT OUT VI Investigators. Comparison of Durable-Polymer Zotarolimus-Eluting and Biodegradable-Polymer Biolimus-Eluting
Coronary Stents in Patients With Coronary Artery Disease: 3-Year Clinical Outcomes in the Randomized SORT OUT VI Trial. JACC Cardiovasc Interv. 2017;10:255-64.

20. Maeng M, Tilsted HH, Jensen LO, Krusell LR, Kaltoft A, Kelbaek H, Villadsen AB, Ravkilde J, Hansen KN, Christiansen EH, Aaroe J, Jensen JS, Kristensen SD, Botker HE, Thuesen L, Madsen M, Thayssen P, Sorensen HT, Lassen JF. Differential clinical outcomes after 1 year versus 5 years in a randomised comparison of zotarolimus-eluting and sirolimus-eluting coronary stents (the SORT OUT III study): a multicentre, open-label, randomised superiority trial. Lancet. 2014;383:2047-56.

21. Jensen LO, Thayssen P, Christiansen EH, Maeng M, Ravkilde J, Hansen KN, Hansen HS, Krusell L, Kaltoft A, Tilsted HH, Berencsi K, Junker A, Lassen JF; SORT OUT IV Investigators. Safety and Efficacy of Everolimus- Versus SirolimusEluting Stents: 5-Year Results From SORT OUT IV. J Am Coll Cardiol. 2016;67:751-62.

22. Bonaa KH, Mannsverk J, Wiseth R, Aaberge L, Myreng Y, Nygard O, Nilsen DW, Klow NE, Uchto M, Trovik T, Bendz B, Stavnes S, Bjornerheim R, Larsen AI, Slette M, Steigen T, Jakobsen OJ, Bleie O, Fossum E, Hanssen TA, Dahl-Eriksen O, Njolstad I, Rasmussen K, Wilsgaard T, Nordrehaug JE; NORSTENT Investigators. Drug-Eluting or Bare-Metal Stents for Coronary Artery Disease. N Engl J Med. 2016;375:1242-52.

23. Stefanini GG, Byrne RA, Serruys PW, de Waha A, Meier B, Massberg S, Jüni P, Schömig A, Windecker S, Kastrati A. Biodegradable polymer drug-eluting stents reduce the risk of stent thrombosis at 4 years in patients undergoing percutaneous coronary intervention: a pooled analysis of individual patient data from the ISAR-TEST 3, ISAR-TEST 4, and LEADERS randomized trials. Eur Heart J. 2012;33:1214-22. 